IDEA - Studia nad strukturą i rozwojem pojęć filozoficznych $\mathrm{XXIX/1}$

\author{
Clifford Meesua Sibani, Fred Ndimafeme \\ (Benin, Awka, Nigeria)
}

\title{
BIBLICAL AND ETHNIC VIOLENCE IN NIGERIA: THE CHRISTIAN APPROACH
}

\section{Introduction}

In viewing ethnicity, six fundamental criteria must be considered: 1 .They must have a name that identifies them as a group. 2 . The must believe in common ancestry. 3. They need to have shared belief about their collective past. 4 . They must have some degree of shared culture generally passed on through a combination of language, religion, laws, customs, institutions, dress, music, crafts, architecture and even food. 5. The group has to have a sense of attachment to a specific territory and 5. Members of the group must believe that they constitute an ethnic group (Haralambos and Holborn) ${ }^{1}$. The genesis of violence is traceable to the family of human ancestry- Adam. Violence form the bloodline of Cain who violently killed his brother Abel brutally depicts wickedness in human heart. Violent actions in today's world show the rate of insecurity. In ethnic and biblical lines, most violence resulted in bloodshed, maiming, brutality and so on. On national basis, marginalization, injustice, political and economic deprivation are some of what leads to violence and crisis. On communal grounds, boundary conflicts emanates during farming seasons in most cases. Rape and sexual violence cannot be overlooked as they have caused terrible conflicts on biblical and ethnic lines. The above conflicts end up in serious wars that linger from age to age and require the intervention of the State. In most

\footnotetext{
${ }^{1}$ Haralambos, M and Holborn, M. Sociology, themes and perspectives, 2008, p.
} 
cases, when conflicts are resolved, the memory of the conflicts remains a perpetual scar on their mind. in some cases violent conflicts occurs when it difficult to distinguish between the offensive and defensive forces of a potential adversary. When they lack combatant adults, infants are employed into militia groups with weapons with a preemptive strike.

\section{Arguments in Favor of Violence}

There are those who love violence and see it to be the solution for conflict resolution. In fact, "if you want peace prepare for war" or "no war no peace". The following arguments are seen as advantages in support of violence especially by the oppressed.

\section{(1) Violence is the Most Natural Response:}

Everyone wants to hit back at his/her enemies and pay them back in the same coin. If the government uses violence to sustain itself in power, the natural response is to use violence to overthrow it.

\section{(2) Violence Produces Results:}

Kunhiyop says when military force is used to topple a dictatorial government; it produces an immediate change, as happened with the overthrow of Idi Amin of Uganda, Nicolae Ceausescu of Romania, Samuel Doe of Liberia and even Saddam Hussein of Iraq ${ }^{2}$.

\section{(3) Violence communicates:}

The message sent by violence is loud and clear and forces a response. It seems to be the only message that some evil and oppressive governments and leaders understand.

(4) Violence is the only option when Dialogue and Diplomacy fail to produce any Change:

When all other forms of protest fail, aggressive action is often seen as the most practical way to alleviate suffering. The use of violence in this circumstance has the backing of philosophical and theological traditions. This brought about the view of Hoekema thus:

\footnotetext{
${ }^{2}$ Kunhiyop, S. W. African Christian ethics, 2008, p. 65
} 
The Just-war tradition, rooted in the ethical theories of Plato and Cicero are formulated within the Christian tradition by Augustine, Aquinas and the Protestant Reformers defends military force as a last resort against grave injustice. According to this view, when the innocent are threatened by an unjust aggressor and all other remedies have failed, Jesus' command for sacrificial love may require us to use lethal force. ${ }^{3}$

\section{Arguments against Violence}

The justification for the use of violence above seems plausible. It is also pertinent to note the problems associated with the use of violence as a response to conflict.

\section{1). Violence Begets Violence:}

It is an indisputable fact that violence attracts violence. This is a true fact as by illustration, we can agree that in Nigeria, especially in Jos and Kaduna in 2001, 2011 and in recent times, young men from the Church and the Mosque took up arms and fought each other. The only result was the destruction of Churches and Mosques and the loss of many lives and properties. The above is still the current trend today. Obviously, the violence solved nothing and simply produced more suffering. According to Wink "If we resist violence with violence, we simply mirror its evil. We become what we resist". ${ }^{4}$ In order to understand this better, Luther stressed that:

Returning hate for hate multiplies hate, adding deeper darkness to a night already devoid of stars. Darkness cannot drive out darkness, only light can do that. Hate multiplies hate, violence multiples violence, and toughness multiplies toughness in a descending spiral of destruction.... The chain reactions of evil - hate begetting hate, wars producing more wars- must be broken, or we shall be plunged into the dark abyss of annihilation. ${ }^{5}$

Violence has never produced peace in our world. It may force a semblance of peace, but violence will eventually erupt again. Kunhiyop says that govern-

\footnotetext{
${ }^{3}$ Hoekema, D. A. (1986). A practical Christian pacifism. Christian Century, 1986, pp.917-918.

${ }^{4}$ Wink, W. Jesus and nonviolence: A third way, 2003, p.73

${ }^{5}$ Luther, M. K. Jr, Strength to love, 1981, p.53
} 
ments that come to power through violent revolution will usually end up being overthrown in yet another violent coup d' etat. $^{6}$

\section{2). Violence Produces more Casualties and Bloodshed}

The use of violence to accomplish some objective or settle some dispute (religious, ethnic, or political) always results in bloodshed and unnecessary loss of innocent lives and property. Kunhiyop is of the view that the Nigerian Civil War of 1967-70 led to the loss of about a million lives. Many millions more have been lost in the Civil and ethnic war in Rwanda, Sierra Leone, Liberia, Nigeria, Congo, Darfur in Sudan, to mention but few. The desired results could have been achieved using non-violent approaches such as dialogue and diplomacy. So many lives have been lost due to violent approach to resolve a dispute or misunderstanding. ${ }^{7}$ Violence is counterproductive and self-defeating; it does not solve conflicts but actually creates more problems than existed before. It hampers the nation's economy, education, disrupts the peace found in the environment, leads to deformity, makes one psychologically sick and above all hinders progress and otherwise.

\section{Violence in Biblical Perspectives}

The concept of injustice and violence in the Christian perspective cannot be understood except there is an in-depth and critical look at violence or crisis in the biblical and theological teachings on the topic. For a proper understanding, a clear view of violence in the Old Testament and in the New Testament will be examined.

\section{(a) Violence in the Old Testament:}

The Hebrew Bible contain story after story of violence against women: e.g. Dinah (Genesis 34), Tamar (2 Samuel 13), the Levite's concubine (Judges 19), Jephthah's daughter (Judges 11), Vashti (Esther 1), Suzannah (Daniel 13), and probably the persistent widow in Luke's Gospel (Luke 18). Later Christian texts also condone male violence against women and the domination of women. For example, the right of chastisement was the enforcer of women's subordination in marriage. Bussert opines that we find the careful instruction to a hus-

\footnotetext{
${ }^{6}$ Kunhiyop, S. W. African Christian ethics, 2008, p. 68

${ }^{7}$ Ibidem, p.68
} 
band to first reprimand his wife thus, "And if this still doesn't work... take up a stick and beat her soundly... for it is better to punish the body and correct the soul than to damage the soul and spare the body". ${ }^{8}$

The principle of "eye for eye and tooth for tooth" (Matt.5:38-41, see Exo. 21:24; Lev. 24: 19-20, Deut 19:21) found in the lex talionis summarized above, depicts unforgiveness and violence in practical terms. This principle of retaliation is found in the famous code of Hammurabi. This code sets a limit for the level of punishment. It is a code that holds that "whatever you want men to do to you, do it to others". Carson posits that "This law provided the nation's judicial system with a ready formula of punishment, not least because it would decisively terminate vendettas". 9

The Old Testament is a book with so many wars including those that were carried out on God's instruction. For instance, the Israelites were commanded by God to drive out the Canaanites and take over their land (Num. 33:50-56; Deut. 20:13; Josh. 3:10). Saul the Kings was also instructed to utterly destroy all the Amalekites (1Sam. 15:2-3). Later, God used the Assyrian and Babylonian armies as tools to punish the nation of Israel and Judah due to their disobedience. What brings defeat on the part of the Israelites nation is when they derail and deviate from the commandments of God.

(b) Violence in the New Testament:

Some of Jesus' teaching specifically addresses the issue of violence. He condemned the act of retaliation and unforgiveness. In Matt.5:38-41, Jesus says:

You have heard that it was said 'Eye for eye, tooth for tooth'. But I tell you, do not resist an evil person. If someone strikes you on the right cheek, turn to him the other also. And if someone wants to sue you and take your tunic, let him have your cloak as well. If someone forces you to go one mile, go with him two miles.

Some say that Jesus is saying that we should never personally respond to insult, but should leave that to the law. Carson holds that "If someone strikes you don't strike back but let the judiciary administer the just return slap". ${ }^{10}$ Some says that Jesus is saying that we should not respond to insult by taking the person to court.

\footnotetext{
${ }^{8}$ Bussert, G. Rules of marriage, 1986, p.13

${ }^{9}$ Carson, A. M. Religion and violence, 2013, p. 155.

${ }^{10}$ Ibidem, p. 155.
} 
In the view of Wink "the verb translated "resist" is the same one used of a violent rebellion, armed revolt, and sharp dissension...a potentially lethal disturbance or armed revolution". ${ }^{11}$ Jesus is condemning any type of violent response. Rom. 12:17-21 reinforces Jesus' words, reminding us not to "reply anyone evil for evil" and to leave revenge to the Lord.

Some are of the view that Jesus is saying that we should passively accept violence and insults and not do anything about them. However, Thompson says that the act of turning the other cheek:

Allows the inferior in the relationship to assert her or his equal human with the oppressor and it forces the oppressor to take stock of the relationship and perhaps of the social system that supports such inequality. It is risky, to be sure, and demands courage, but it is a creative way to challenge an unhealthy relationship and unjust system. Both Gandhi and Martin Luther King Jr. grasped this well and molded this idea into a tool for resisting social injustice and creating a more just community. ${ }^{12}$

Wink (cited in Kunhiyop), makes the same point there:

This action robs the oppressor of the power to humiliate. The person who turns the other cheek is saying in effect "try again. Your first blow failed to achieve its intended effect. I deny you the power to humiliate me. I am a human being just like you. Your status does not alter that fact. You cannot demean me" such response would create enormous difficulties for the striker....Even if he orders the person flogged; the point has been irrevocably made. The oppressor has been forced, against his will, to regard this subordinate as an equal human being. The powerful person has been stripped of his power to dehumanize the other. This response, far from admonishing passivity and cowardice, is an act of defiance. ${ }^{13}$

Luke 22:36-38 gives an account that makes some to think of Jesus to be a pacifist.

Now if you have a purse, take it, and also a bag; and if you don't have a sword, sell your cloak and buy one. It is written: And he was numbered with the transgressors; and I tell you that this must be fulfilled in me. Yes, what is written about me is

\footnotetext{
${ }^{11}$ Wink, W. Jesus and nonviolence: A third way, 2003, p. 11.

${ }^{12}$ Thompson M. Justice and peace: A Christian primer, 2003, p. 192.

${ }^{13}$ Kunhiyop, S. W. African Christian ethics, 2008, p. 117.
} 
reaching its fulfillment. The disciples said, see, Lord, here are two swords. That is enough, he replied.

Ferguson states that "This is undoubtedly the most difficult passage in the New Testament to reconcile with the general tenor of Jesus' teaching of nonviolent love". ${ }^{14}$

This passage sounds contradictory to the other statements Jesus made that seem to prohibit the use of swords as enshrined in (Matt. 26:52; John 18:36). Thus, some scholars prefer to interpret this passage metaphorically. William (cited in Ferguson), states that it is "a vivid eastern way of telling the disciples that their very lives are at stake" ${ }^{15}$ But an ordinary reading of the passage suggests that when Jesus instructed his disciples to take a sword, he was simply acknowledging the reality of violence. It helps to remember the historical context in which Jesus was speaking. It was common for men to carry swords in those days. Jesus is acknowledging that swords may be needed for self- protection. When the authorities provide no proper protection, it is appropriate to protect oneself.

Advocating on nonviolent response to oppression and injustice is not at odds with self-defense or defense of one's family or even one's church. However, Kunhiyop is of the view that in Nigeria where families and churches have been targeted for destruction, it would be appropriate for a Christian to use a weapon to protect himself and his family. It is unwise and irrational not to protect one's household if it is being attacked. ${ }^{16}$ Jesus' view of violence in a way gives a contradiction as we see Matt. 26:52 "Put your sword back in its place... for all who draw the sword will die by the sword".

Kenneth avers that it is very clear that this passage is usually used by Christians to condemn any form or use of violence or force. It should also be clear that the context in which Jesus made this statement was at the point of his arrest. This means that Jesus deemed it unnecessary and useless to use a sword or any weapon to accomplish a divine purpose. Jesus had earlier stated that in the process of fulfilling his mission, he would die a violent death. Hence, it was inappropriate for the disciples to attempt to prevent this. ${ }^{17}$ It should be on note

\footnotetext{
${ }^{14}$ Ferguson, J. The politics of love: The New Testament and nonviolent revolution, 1973, p. 31.

${ }^{15}$ Ibidem, p. 33.

${ }^{16}$ Kunhiyop, S. W. African Christian ethics, 2008, p. 120.

${ }^{17}$ Kenneth, A. O. The sword in the biblical context, 2016, p. 96.
} 
that Jesus only told Peter to put his sword back in its place. He did not tell him to throw it away, or destroy it, or never to use it again in any circumstances. $\mathrm{He}$ only said that he who kills by the sword will die by the sword. It does not mean that Jesus prohibited the use of sword for self-defense, as it is clear from his command in Luke 22.

In John 18:36, Jesus addressed Pilate thus: "My kingdom is not of this world. If it were, my servants would fight to prevent my arrest". This means that if the kingship of Christ was of this world, then Jesus would have commanded his disciples to go into battle where lives and property would have been destroyed. Luther has argued that the above world of Christ gives permission to earthly nations to go to war if there are adequate reasons. However, it would be true that Jesus was making reference to his spiritual kingdom which has enough resources of its own to be victorious if it were to engage in an actual physical war with the kingdom of this world (Matt. 26:53). ${ }^{18}$

\section{Ethnic Crisis in Nigeria}

Western discussions of the ethics is the focus on the responsibilities of citizens in time of war, non-resistance, pacifism, preventive war and what constitutes a just war. In Africa, conflicts occur between factions within a state (civil war), between ethnic groups (ethnic war), or between two religions (religious war). Thompson holds that:

Most wars in Africa arise from tensions between ethnic groups within the same state. Ethnicity is a characteristic of a group of people, whether a few thousand or several million, who share a persisting sense of common interest and identity that is based on some combination of shared historical experience and valued cultural traits. $^{19}$

This of course is associated with shared culture, language, religion, social customs, physical appearance and geographic origins, and affects people who look for security and protection. Ethnic consciousness and interests often lead to conflict and violence. The complexity of ethnic and religious conflicts can

\footnotetext{
${ }^{18}$ Luther, M. K. Jr, (1981). Strength to love, 1981, p. 58.

${ }^{19}$ Thompson M. Justice and peace: A Christian primer, 2003, p. 116.
} 
only have solution through negotiation and dialogue. The conflict associated with ethnicity and religiosity sometime spill across political boundaries and affect neighboring countries.

It is obvious that ethnic conflicts can be exacerbated when there are also religious differences between parties. Thus, Thompson posits:

Religion is one of the features that can distinguish one ethnic group from another. Since religion pertains to core values, it can inflate the intensity and intractability of ethnic conflict. Religious belief can even be used to legitimate or authorize intolerance toward another ethnic group. ${ }^{20}$

What more can be said as the above conditions do not exonerate Nigeria from the picture of religious violence, conflict and crises. The religious and ethnic crisis in Nigeria which has been and is still going on between Christian and Muslim has really affected all sphere of the nation. Some see it to be political; however, the Church is also in battle within itself. Criticisms arises even among churches and to a great extent, it has affected the centre and weaken the religious voices in the Nigerian nations.

Conflict occurs as a result of a person's or a group action being perceived by another person or group as injurious to the other person or group. Egwu states that in the Niger Delta Region of Nigeria, the struggle for self determination is fueled by a different political dynamic which over time, has led to the transformation of ethnic minority consciousness. Here, it is framed by the structure of political domination in post colonial Nigeria, and in particular, the alliance between the Nigerian State and Oil Transnational Companies. Ethnic minorities such as the Ogoni of Rivers State, Ijaw of Bayelsa State, and Urhobo of Delta State, for example, consider the acute poverty and neglect of their region as well as ecological devastation despite the huge deposits of crude petroleum which has remained the life-wire of the Nigerian state, to be a consequence of their minority status in a country in which the construction of state power is understood to be predicted on the interests of the ethnic minorities. In response to the feeling of marginalization and exclusion, they have made a number of demands on the Nigerian State which touch on the question of selfdetermination, and which has precipitated a chain of violent reactions. Not unexpectedly, the Ogoni like several other communities, have demanded the right

${ }^{20}$ Thompson M. Justice and peace: A Christian primer, 2003, p. 121 
to control and use a fair share of Ogoni economic resources for Ogoni development, adequate and direct representation in national institutions, and the development of Ogoni language and culture, among others. ${ }^{21}$

\section{Causes of Ethnic Conflicts in Nigeria}

There are several reasons why ethnic and religious crisis occur in the world today. Kwame avers that these causes include "a reaction against overcentralized, corrupt and exploitative governments, a search for cultural identity amid the constant changes and confusion of modern society and alienation, which threatens the very roots of community". ${ }^{22}$ However, Kunhiyop says that in Africa, the conflicts are also being driven by profound forces of change in the economic and political spheres, increased human migration, resentment of injustice, both real and perceived. ${ }^{23}$

\section{Economic change}

The growth of the economy of a nation is accompanied with people seeing their lives improving and hope to be able to share in their nation's abundance. However, economic tensions, arise if the rate of economic growth slows. To this end, Masipula (1985:85) posits that when this occurs, "ethnic identity will become more salient. This is due to competition over scarce resources, or in this case, a shrinking pie". ${ }^{24}$ Lloyd (1974:223) avers that economic tension also rises "when new resources, hitherto unallocated, are to be distributed, and... when the new patterns of distribution create alterations in the existing ranking of individuals". ${ }^{25}$ The inflation that often accompanies economic change worsens the

${ }^{21}$ Egwu S. G. Beyond revival of old hatreds: The state and conflict in Africa. In S. G. Best (E.d). Introduction to Peace and Conflict Studies in West Africa, 2009, pp. 406-407.

${ }^{22}$ Kwame, Y. The impact of globalization on African culture, 2006, p.23

${ }^{23}$ Kunhiyop, S. W. African Christian ethics, 2008, p. 34

${ }^{24}$ Masipula S. The salience of ethnicity in African politics: The case of Zimbabwe. Journal of Asian and African Studies 20, 1985, p.185

${ }^{25}$ Lloyd, P. C. Ethnicity and the structure of inequality in a Nigeria town in the mid 1950's. in A. Cohen (Ed.). Urban Ethnicity, 1974, p. 223 
situation and exacerbates tensions. The Nigeria Delta Region of Nigeria has generated conflicts because of the discovery of oil in their land which is explored and exploited without any corresponding development and fair share of the resources derived from their oil, hence their agitation for "resource control".

Kunhiyop is of the view that the problem is not the booming economy but the distribution of the new wealth. Economic disparity among citizens, where the rich becomes richer and the poor becomes poorer, worsens the situation. Competition for wealth and power among many African countries involve groups that are divided on cultural or religious lines. In Nigeria and Kenya, for instance, some ethnic groups are wealthier than others and have more of their own businesses and better access to top government positions. ${ }^{26}$ When any ethnic conflict arises, rich people from those groups are targeted and suffer the anger of the poor.

\section{Political Change}

Due to the prevalence of patronage syndrome in Africa, our political leaders are at liberty to use their official positions to amass wealth for themselves or members of their own ethnic group or class. Masipula contends that social stratification opens room for "position of power, status and prestige...assigned according to ones membership in a particular ethnic group" ${ }^{27}$. He maintained thus:

The salience of ethnicity will increase as individuals of lowly ranked ethnic groups attempt to rise into positions hitherto the monopoly of those higher in the ethnic social structure. As the former make a claim to power, status and prestige, the latter close ranks to defend the same. The ensuring conflict takes on an ethnic flavor because the lines of battle are structured along ethnic lines. ${ }^{28}$

The struggle for power in Nigeria has long been generating conflict in the Nigerian nation. This has made the Hausa- Fulani who are predominantly Muslim to grip the key to political power in Nigeria since independence. The

\footnotetext{
${ }^{26}$ Kunhiyop, S. W. African Christian ethics, 2008, p. 56

${ }^{27}$ Masipula S. The salience of ethnicity in African politics: The case of Zimbabwe. Journal of Asian and African Studies 20, 1985, p.187

${ }^{28}$ Ibidem, p. 187
} 
Yoruba and Igbo people have not relented in the struggle to control Nigeria from Aso Rock. Of course, many other smaller groups in the nation are not relenting in the struggle to gain recognition. Similar ethnic struggle are in Kenya, Liberia, Congo, Sudan, Ethiopia and Uganda. No doubt, these ethnic struggles for power can flare into violence when one group does not get what it desires. The consequences of these conflicts can fragment the State.

\section{Human Migration}

There is always tension when a particular ethnic group migrates from one place to the other for settlement already occupied by other groups, regardless of whether the area is rural or urban. On basis of ethnicity, Lloyd avers that:

Just as in the rural area, a man turns for help to the members of his own descent (ancestral) group or small village, so when he comes to the town does he seek the support of those related closely to him by ties of Kinship or locality. ${ }^{29}$

Kunhiyop is of the view that ethnic groups hold their tribal meetings to set up political pressure groups, clubs and so on to promote their own interests. The situation highlights the differences between groups and does nothing to encourage national unity. ${ }^{30}$

\section{Real or Perceived Injustice}

Injustice flows in the vein of so many privileged ones in the society. Helder says that "injustice affect millions of human beings, children of God, reducing them to a sub-human condition". ${ }^{31}$ The human society especially in Nigeria lack portable water and endure political oppression and degradation, unemployment and insecurity. He further stated that poverty:

\footnotetext{
${ }^{29}$ Lloyd, P. C. Ethnicity and the structure of inequality in a Nigeria town in the mid 1950 's. in A. Cohen (Ed.). Urban Ethnicity, 1974, p. 224

${ }^{30}$ Kunhiyop, S. W. African Christian ethics, 2008, p. 73

${ }^{31}$ Helder, C. Spiral of violence, 1971, p. 25
} 
...does more than kill, it leads to physical deformity (just think of Biafra), the psychological deformity (there are many cases of mental sub-normality for which hunger is responsible), and the moral deformity (those who, through a situation of slavery, hidden but nonetheless real, are living without prospects and without hope, foundering in fatalism and reduced to a begging mentality). ${ }^{32}$

This king of injustice is seen as violence and leads to greater violence as the oppressed turn on the oppressor.

\section{Solutions to Ethnic Violence}

There are some methods that are pertinent in the resolution of conflicts. These methods will be looked into in the light of negotiation, mediation, arbitration and adjudication.

\section{(1) Negotiation:}

Negotiation is a structured process of dialogue between conflicting parties about issues in which opinion differ. Here, the parties involved know that they have a problem and are both aware that by talking to each other, they can find a solution to the problem. Bode posits that when communication is threatened or has stopped, it become appropriate to send mandated representative of each party to meet and find ways to resolve the issue and as well reach agreement and consensus ${ }^{33}$.

Negotiation often involve compromise for instance, one group may win one of their demands and give in on another. However, political and community groups, various unions and management do use this method to resolve their conflicts. Obinna holds that negotiation which is often based on dialogue has a universal application as a principle of conflict management. ${ }^{34}$ Timing is very necessary and it would not be appropriate to go in for negotiation when the degree of anger on either side is very high. When this state of high degree of anger is found, then negotiation should be rescheduled.

\footnotetext{
32 Ibidem, p.28

${ }^{33}$ Bode, H. Dispute and negotiation, 2015, p. 96

${ }^{34}$ Obinna, D. Negotiation in a conflict stricken society, 2014, p. 17
} 


\section{(2) Mediation:}

This is a process in which a third party intervenes to help individuals or groups in a conflict to resolve their differences. Uchendu saw mediation as the voluntary, informal, non-binding process undertaken by an external party that fosters the settlement of differences or demands between directly invested parties. Here, the mediator manages negotiation process, but does not impose a solution on the third parties. When two friends quarrel or disagree, another friend could be a mediator in the relationship. The intervention of a mediator is to help the conflicting parties or groups reach a solution to their problem. ${ }^{35}$

The mediator helps the conflicting parties have an enabling environment for dialogue leading to the resolution of the problem. He must not aggravate the situation but proffer solution by leading the parties to win-win outcome of the conflict and not win-lose outcome. Uchendu saw mediators in three forms: (a) Social Network Mediators (b) Authoritative mediators and (c) Independent mediators.

\section{(a) Social Network mediators:}

These are people who because they are either in close relationship with the conflicting parties or due to the fact that they belong to the same network (or social group) with the conflicting parties, are invited to intervene in a conflict. Their position in the resolution of that conflict is based on their affinity, trust and confidence to resolve the conflict. These groups of people are for instance, family friends, members of the same religious groups, neighbors, office mates etc.

\section{(b) Authoritative mediators:}

Here it refers to those who by their position are in control over something which the people facing conflict value so much. The use of their power and authority to persuade the conflicting parties to resolve the conflict amicably is inevitable. Example of this group of people is a superior officer (Such as General Manager) in an organization could mediate in a conflict involving subordinate in such organization.

\section{(c) Independent Mediators:}

Here, it refers to neutral individuals, groups or organization that do not have vested interest in the conflict and therefore must not be partial in their efforts to resolve the conflicts and settle the problems. Some of the members of

\footnotetext{
${ }^{35}$ Uchendu, E. R. Conflict mediation, 2010, p. 78.
} 
this group are trained and skilled in the work of mediation and some do have mediation firms that could be consulted to resolve conflicts.

\section{(2) Arbitration:}

Arbitration is the use and assistance of a neutral party (third party) in conflict, who hears the evidence from both parties after which he takes a decision which is expected to be binding on the parties. Arbitration is similar to mediation but different in the sense that the decisions of the arbitrator is binding upon the parties, while in ordinary mediation, his decisions are not binding. Best (cited in Uchendu) states that "Arbitrators fulfill their role by virtue of the position of authority they occupy in the society. They could be traditional leaders in the family, clan, village, community, ethnic group etc". ${ }^{36}$ It is expected that the outcome in any arbitration process is a fair one. Most of these methods of conflict management have so many things in common. For instance, negotiation, mediation and arbitration, all depend on communication, dialogue and negotiation.

\section{(3) Adjudication:}

This is the management of crisis through a judicial procedure. It is another non-violent method of conflict management which involves the use of the courts and litigation processes. Parties to a dispute may decide not to use any of the methods mentioned above but rather prefer to take their case to a court of law, before a judge of competent jurisdiction. Legal counsels (Lawyers) are employed to represent them. At the end of the legal battle, the court gives a judgment. The judgment will be further enforced where necessary by the law enforcement agencies of the state. It is worthy of note that litigations also end in win-lose outcomes where a winner and a loser emerges and as such the bitterness remains.

\section{Application of Christian Principles as Remedy to Violence}

The ethnic and religious conflicts in Africa cannot be solved by violence. Gerard posits:

\footnotetext{
${ }^{36}$ Ibidem, p. 79.
} 
Because of their intractable and explosive nature, ethnic conflicts can be resolved only through political dialogue and negotiation. War and violence...serve only to exacerbate them. Nor are political solutions alone sufficient. It is necessary to apply the Christian principle which goes a long way to seek healing and reconciliation because that is what the church is called to $\mathrm{do}^{37}$.

There should be promotion of justice because "everyone must submit to the governing authorities", "turn the other cheek", "love your enemies" and "all who draw the sword will perish by the sword". Miller avers:

When church leaders preach reconciliation without having unequivocally committed themselves to struggle on the side of the oppressed for justice, they are caught straddling a pseudo neutrality made of nothing but thin air. Neutrality in a situation of oppression always supports the status quo. Reduction of conflict by means of a phony "peace' is not a Christian goal. Justice is the goal, and that may require an acceleration of conflict as a necessary state in forcing those in power to bring about genuine change $\mathrm{e}^{38}$.

Here the church must be seen to be involved in an active struggle against injustice, ethnocentrism and oppression. Where there is fairness and equity for all ethnic and religious groups in respect of employment, political appointments, school admissions and all normal amenities in any of our communities, there is greater willingness to accept people from other ethnic groups. Thus, promoting justice is the greatest avenue for reducing ethnic and religious conflicts in Africa.

We must love and learn to forgive our enemies and as well pray for them (Matt.5:44-45). Luther says "No one is so wicked that there is no good element in them; and no one is so good that there is no bad element in them" ${ }^{39}$. This made Stott to state thus:

We human beings have both a unique dignity as creatures made in God's image and a unique depravity as sinners under his judgment. The former gives us hope; the latter places a limit on our expectations...the Christian mind, firmly rooted in biblical realism, both celebrates the glory and deplores the shame of our human

\footnotetext{
${ }^{37}$ Gerard, F. P. Peacemaking: moral and policy challenges for a new world, 1994, p. 329

${ }^{38}$ Miller, W. R. Nonviolence: A Christian interpretation,1966, p.168

${ }^{39}$ Luther, M. K. Jr, Strength to love, 1981, p. 51
} 
being. We can behave like God in whose image we were made, only to descend to the level of the beasts. We are able to think, choose, create, love and worship, but also to refuse to think, to choose evil, to destroy, to hate, and to worship ourselves. We build churches and drop bombs... This is 'man', a strange, bewildering paradox, dust of earth and breath of God, shame and glory ${ }^{40}$.

Forgiveness is not easy but we must forgive. Luther struggled to tell us that he had much to forgive by saying "we must develop and maintain the capacity to forgive. He who is devoid of the power to forgive is devoid of the power to love". ${ }^{41} \mathrm{He}$ also stressed that the forgiving act must always be initiated by the person who has been wronged, the victim of some great hurt, the recipient of some tortuous injustice, the absorber of some terrible act of oppression. Forgiveness is the true test of authentic Christian faith. However, Wink has this to say:

Commitment to justice, liberation, or the overthrow of oppression is not enough, for all too often the means used have brought in their wake new injustices and oppressions. Love of enemies is the recognition that the enemy, too, is a child of God. ${ }^{42}$

Only love for enemy and the determination not to use force or violence will win conflicts and win the enemy. These attitudes provide a theological base framework within which to carry on the vital task of building structures that can eventually eliminate war and its causes in our society. Let us note that there is a violence that liberates and there is a violence that enslaves; there is a violence that is moral and there is a violence that is immoral. The choice is yours.

\section{Recommendations}

1.) Peace seeking via dialogue should be used as a way forward.

2.) Violence begets violence. A compromise should be reached.

3.) The Christian principle of forgiveness and love should be embraced.

\footnotetext{
${ }^{40}$ Stott, J. Nerw issues facing Christians today, 1999, p. 44

${ }^{41}$ Luther, M. K. Jr, Strength to love, 1981, p. 50

${ }^{42}$ Wink, W. Jesus and nonviolence: A third way, 2003, p. 59
} 
4.) The government should not create violence by marginalizing the poor masses but should protect their rights.

5.) True justice should prevail in Nigeria to protect lives and property.

\section{Conclusion}

Considering the concept of violence in the Bible and ethnic groups in $\mathrm{Ni}-$ geria, this research has shown that there are those who perpetrate violence for their selfish aim. They argue that the act of violence is the only way to obtain peace. Others see it in the reverse that violence has no good to offer to lives and property. Hence, peace-seeking is their language. Wars and misunderstanding took place in the Bible just like in Nigeria where insecurity rocks virtually every community. Some major causes of this violence have been discussed and solution proffered. To forestall further violence, recommendations has been put forward for peaceful co-existence.

\section{Summary}

Violence exists in every facet of life and it is amazing that it is found in the Holy Bible. Also, in every ethnic group, violence is seen. The results produced by biblical and ethnic violence in Nigeria are very enormous. It is discovered that violence leads to death, displacement, restricts movements amongst people in contest. This research addressed several arguments for and against violence, violence in the biblical perspective, ethnic crisis in Nigeria, causes of ethnic crisis in $\mathrm{Ni}$ geria, solutions to ethnic violence and application of Christian principles as remedy to violence. Historical method is being adopted in this research. The research therefore recommends that peace seeking via dialogue should be used as a way forward.

Key words: the Holy Bible, violence, death, crisis, Nigeria

\section{Bibliography}

Bode, H. (2015). Dispute and negotiation. Ibadan: Ugobest.

Bussert, G. (1986). Rules of marriage. New York: Kalipa Books

Carson, A. M. (2013). Religion and violence. London: Carpix.

Egwu S. G. (2009). Beyond revival of old hatreds: The state and conflict in Africa. In S. G. Best

(E.d). Introduction to Peace and Conflict Studies in West Africa, 406-443. Owerri: Spectrum.

Ferguson, J. (1973). The politics of love: The New Testament and nonviolent revolution. Cambridge:

James Clarke. 
Gerard, F. P. (1994). Peacemaking: moral and policy challenges for a new world. Washington: United States Catholic Conference.

Haralambos, M and Holborn, M. (2008). Sociology, themes and perspectives. London: HarperCollins.

Helder, C. (1971). Spiral of violence. London: Sheed \&Ward.

Hoekema, D. A. (1986). A practical Christian pacifism. Christian Century, 912-918.

Kenneth, A. O. (2016). The sword in the biblical context. Umuahia: Cana publishers

Kunhiyop, S. W. (2008). African Christian ethics. Zondervan: Hippo Books.

Kwame, Y. (2006). The impact of globalization on African culture. Odense: University of Southern Denmark.

Lloyd, P. C. (1974). Ethnicity and the structure of inequality in a Nigeria town in the mid 1950's.

In A. Cohen (Ed.). Urban Ethnicity, 221-235. New York: Tavistock.

Luther, M. K. Jr, (1981). Strength to love. Philadelphia: Fortress.

Masipula S. (1985). The salience of ethnicity in African politics: The case of Zimbabwe. Journal of Asian and African Studies 20, 175-185.

Miller, W. R. (1966). Nonviolence: A Christian interpretation. New York: Shocken Books.

Obinna, D. (2014). Negotiation in a conflict stricken society. Uyo: Akpan-Udo.

Stott, J. (1999). Nerw issues facing Christians today. London: Marshall Pickering.

Thompson M. (2003). Justice and peace: A Christian primer. Maryknoll: Orbis.

Uchendu, E. R. (2010). Conflict mediation. Jos: Oburu press.

Wink, W. (2003). Jesus and nonviolence: A third way. Minneapolis: Fortress.

Very Rev. Clifford Meesua Sibani Ph.D

Department of Religions, University of Benin, Nigeria

Rev. Fr. Fred Ndimaeme Ph.D

Nnamdi Azikiwe University, Awka, Nigeria 